\title{
THE MODERATING EFFECT OF TECHNOLOGY UTILIZATION ON PROJECT MANAGEMENT FUNCTION AND PROJECT PERFORMANCE
}

\author{
HAFNIDAR ABDUL RANI \\ CHE SOBRY ABDULLAH \\ SHAHIMI MOHTAR \\ School of Technology Management \& Logistics \\ UUM College of Business \\ Universiti Utara Malaysia
}

\begin{abstract}
This study investigated the moderating effects of technology utilization on the relationship between project management function and project performance. The project management function element is operationalized by nine constructs and the technology utilization element examined in this study focuses on three factors. Data was collected using the questionnaire survey approach. This study employed the stratified random sampling procedure in selecting businesses and organizations, that included the construction industry in the sample. Four hundred and forty eight Aceh construction organizations participated in this study. Partial correlation analysis was utilized for hypotheses testing. In general, the result of the partial correlation analysis showed that technology utilization moderated the relationship between seven of the nine functions of project management and overall project performance. Individually, these three variables of technology utilization did not moderate the relationship between communication management and cost performance. The outcome of this study provided vital information on the relationship between project management function, technology utilization and project performance in the Aceh construction organizations. This study also provided an insight into further understanding of the issue of interface between project management function, technology utilization and project performance.
\end{abstract}

Keywords: Project management, project management function, technology utilization, project performance, partial correlation.

\section{Introduction}

Since the late 1960s (at least) project management researchers have been trying to discover which factors lead to project performance (e.g. Baker \& Murphy, 1988; Pinto \& Slevin, 1988) and have reached conclusions that have been widely reflected in literature written for project management practitioners (Cooke \& Davies, 2002).
Most of the early studies in the area focused on the reasons for project failure rather than project success. In those studies it was assumed that if a project completion time exceeded its due date, or expenses overran the budget, or outcomes did not satisfy a company's pre-determined performance criteria, the project was assumed to be a failure. Today we know that determining whether a project is a success or a failure is far more complex (Belassi \& Tukel, 1996). 
In recent decades, there has been a remarkable growth in the number, size, and complexity of large infrastructure projects in many developing countries. The management of projects deal with the will of uncertainty that may arise from the projects. Uncertainty is the root cause of project delays and a decrease in organizational performance (Ofori, 1991; Ogunlana, Promkuntong, \& Jearkjirm, 1996).

The performance of the projects that achieved success by several contractors in implementing projects was due to experience in managing the projects and possesing good reputation in the government of Indonesia, but not project management. Conversely, the failure of the projects in Indonesia were caused by several items, including: lack of monitoring and coordination. Thus, the effectiveness of project management in Indonesia is still low (Bay et al., 2005).

Aceh is one of the 32 regions in the country of Indonesia. Banda Aceh is the capital of the Aceh region, the most affected by the tsunami of six years ago (December 26, 2004). To avoid failure of the projects in the Province of Aceh, the Rehabilitation and Reconstruction Agency (BRR) took a role in the planning, construction design and supervision, which was conducted by the contractors, who had been given the large number of infrastructure development that had to be rebuilt so that the new buildings would be better than before (Reza, 2006).

As the reconstruction and recovery programme took place after the tsunami in the Aceh slump on December 26 2004, and resources and finance available were very limited, the project implementers had to improve the efficiency and effectiveness of project management (Wood, 2008).

The scope of this study is limited to Aceh Province. The construction/contractor organizations in the Province of Aceh had 2,334 contractors, who managed grade 2 to grade 7 construction projects (Lembaga Pengusaha Jasa Konstruksi Indonesia, 2009).

The problem was: can technology utilization affect project performance?

Based on the issues above, the objective of this study was: to investigate the influence of technology utilization on the relationship between the functions of project management and project performance.

\section{Literature Review}

\section{Project Management}

Project management can be used as a tool to maximize the performance of a project (Jaselskis \& Ashley, 1991). Empirically, there is strong evidence that the practice of project management knowledge can affect project performance.

The search for factors that lead to better project performance and success spans many years of research. The project management literature has dealt extensively with factors affecting project performance (Pinto \& Slevin, 1988).

According to the PMI's A Guide to the Project Management Body of Knowledge, or the PMBOK Guide, project management is the application of knowledge, skill, tools, and techniques to a broad range of activities in order to meet the requirements of a particular project (Project Management Institute, 2000).

Project management is one of the fastest growing disciplines in organizations today (Shenhar \& Dvir, 2007), and it is one of the crucial aspects of the entire construction process (Levy, 2000). Project management, as a profession and area of research, continues to grow and develop. In response to project management being applied in new industries, countries and application areas, the demands on project management continue to change (Crawford et al., 2005). 
For almost 30 years, project management was viewed as a process that might be nice to have, but not one that was necessary for the survival of the firm. Companies reluctantly invested in some training courses simply to provide their personnel with the basic knowledge on planning and scheduling. Project management was viewed as a threat to established lines of authority and, in most cases, only partial project management was used. This half-hearted implementation occurred simply to placate lower and middlelevel personnel (Kerzner, 2000).

The topic of promise to researchers (Morris \& Hough, 1986) who focus on project management is the application of the Project Management Body of Knowledge (PMBOK) which is one way to improve the project performance used as a lens for the research of project management (Project Management Institute, 2000). Morris and Hough (1986) used project function, project management and the contractor's business performance to measure project performance.

\section{The Project Management Body of Knowledge} describes project management knowledge and practice in terms of their component processes. These processes have been organized into nine areas: project integration management, project scope management, project time management, project cost management, project quality management, project human resource management, project communications management, project risk management, and project procurement management (Project Management Institute, 2000).

\section{Project Performance}

Performance is a matter that is not tangible, especially in the case of management performance. So an assessment tool to better project performance is required to create the best of the best organization (Qureshi, Warraich, \& Hijazi, 2009).

The definition of project performance is vague and there is no universal acceptance criteria used for its measurement (Jha \& Iyer, 2007). Lim and Mohamed (1999) defined criteria as the set of principles or standards by which judgement is made and are considered to be the of the game.

According to Khang and Moe (2008), project performance is measured against the achievement of the project owner's strategic organizational objectives and goals, as well as the satisfaction of the users and key stakeholders' needs where they relate to the project's final product.

One of the functions of construction project management is to ensure the performance of the construction project. However achieving success in a construction project is not a small task. Moreover, the measurement of the performance of a construction project itself is considered to be a debatable issue as there are no universally accepted criteria for it (Jha \& Iyer, 2007).

\section{Project Performance Factors}

Project performance factors are elements of the project or its management that can be influenced to increase the chance of achieving a successful outcome. The reverse-pitfalls-are management mistakes which increase the chance of failure (Morris and Hough, 1987; Wateridge, 1998; Jugdev \& Müller, 2005; Turner, 2009).

Traditionally project performance is evaluated using schedule, cost, and quality performances, also known as the "iron triangle" (Atkinson, 1999). Subsequently a number of researchers have proposed different sets of performance evaluation criteria in addition to the iron triangle.

The Project Management Institute (1996; 2000) classifies nine knowledge functional areas: project integration management, project scope management, project time management, project cost management, project quality management, project human resource management, project communications management, project risk management, and project procurement management. 
A good project governance concept is developed to evaluate the performance of this project, especially in strategic issues. Such an evaluation is necessary to assess the project's overall performance in addition to evaluating the project management process and product performance (Abednego \& Ogunlana, 2006).

\section{Project Performance Criteria}

Project performance criteria are the measures by which we judge the successful outcome of a project (Morris \& Hough, 1987; Wateridge, 1998; Jugdev \& Müller, 2005; Turner, 2009).

Defining criteria to measure project performance has been recognized as a difficult and controversial task (Baccarini, 1999; Liu \& Walker, 1998). Performance and failure attributes have varying impacts on performance, which depends upon the performance criteria adopted by the researchers. While some of the factors have been highlighted to be too important and critical in one literature, the same factors may not bear any recognition in the other (Thomas, Tucker \& Kelly, 1998; Sadeh, Dvir, \& Shenhar, 2000; Bower, Ashby, Gerald, \& Smyk, 2002; Lim \& Ling, 2002; Dvir, Raz, \& Shenhar, 2003).

Time, cost and quality are the basic criteria to project performance. Nearly every related article mentions these three and point out their importance in a construction project. Project participants, such as Walker (1995;1996), Belassi and Tukel (1996), Hatush and Skitmore (1997), Pinto and Slevin (1988), Archibald (1992), Baccarini (1999), Turner (1993), Westerveld (2003), Belout and Gauvreau (2004) have the some views.

Atkinson (1999) identified these three criteria as the "Iron Triangle". The three of them are the important parameters to the project managers who are usually associated as the project's target. The measure of project performance is how far the triple constraints can be filled out
(Soeharto,1998). Also time, cost and quality are three important indicators to measure construction project performance (Meng, 2012).

Performance was defined as one where the stakeholders are satisfied with the outcomes. These elements were noted by both Morris and Hough (1987) and by Turner (1999). The inclusion of satisfaction as a performance measure can be found earlier in the work of Wueliner (1990). Munns (1995) investigated whether cost, time, quality and customer satisfaction were the criteria for project performance.

However, the majority of research practitioners (Pinto \& Slevin, 1988; Freeman, 1992; Shenhar \& Levy, 1997; Baccarini, 1999) considered project performance as an important project management issue (Crawford, 2000). For instance, the PMBOK guide published by the Project Management Institute (1996) suggested that project performance criteria should include the "iron triangle" and key project stakeholder satisfaction (Wang \& Huang, 2006).

Project stakeholders are individuals and organization who are actively involved in the project, or whose interests may be positively or negatively affected as a result of project execution or performance project completion (Project Management Institute, 1996). The project management team must identify the stakeholders, determine what their needs and expectations are, and then manage and influence those expectations to ensure a performance project. So stakeholder satisfaction is a crucial part of project performance (Yang et al., 2011).

\section{Technology Utilization}

Technology as a critical component enables knowledge management. Information technology, having a solid foundation for solutions that automate focuses on development, application, dissemination and sharing knowledge. The 
management tool that enables technological knowledge enhances knowledge generation, codification and transfer. Knowledge of technology tools can be categorized into four technology areas such as hardware, software and databases, collaboration tools and intelligent devices (Rasli et al., 2004).

Many studies have shown that the construction industry is reluctant to apply new technologies and employs lower levels of technology than other industries. A national-wide survey conducted by the Civil Engineering Research Foundation indicated that the design and construction industry spent only $0.5 \%$ of its total revenues on research and development (Civil Engineering Research Foundation, 1997).

Two hundred and nine completed projects from across the U.S. have each been assessed for the levels of technology employed on 68 different common project work functions. In addition, the projects have been assessed for the levels of overall project cost and the schedule performance attained. Specially, project technology usage findings were presented and analysed according to project size. Composite project performance (a combination of project cost and schedule performance) findings were also presented and relationships with technology usage were discussed. The results indicated that the project performance technology relationships for medium and small projects were stronger than those for large projects. For medium and small projects, the levels of project technology usage were positively associated with the projects' levels of composite performance (Yang et al., 2006).

Back and Bell (1994) attempted to identify the impacts of the use of electronic data interchange in bulk materials management. A process model was developed during this research. In order to identify technology benefits, the analysis results from the integrated models were compared with those from non-integrated models. The findings indicated that integration resulted in a cycle time reduction in bulk materials process.

However, the family of project management tools is of general purpose in nature and does not include specialized software sizing and estimating capabilities as do the software cost estimating tools. Neither do these general project management tools deal with quality issues such as defect removal efficiency. Project management tools are useful, but the software requires additional capabilities to be under fullmanagement control.

According to Rose and Suhanic (2001), today's project manager can choose from a great many computer tools. Computer-aided project management is a resource to help identify the specific job of the various computer software, and most importantly, to help integrate computer tools in support of all the systems of project management. Computerization is to carry out more than the role of project management. However, perhaps it is the same as making a bad schedule, cost estimate, or a portion critical with software packages manually (Jiang, 2001).

\section{Theoretical Framework}

Based on the literature review discussed, a framework was devised to investigate the project management function of the Project Management Body of Knowledge and technology utilization on project performance. Figure 1 depicts these relationships. This framework is derived from the review of the theories, concepts and the elements involved in the project management.

This model should be viewed as the overall framework for the analysis. The independent variable in this framework is project management function. On the other hand, the dependent variable is project performance. Technology utilization serves as the intermediate between project management function and project performance in this framework. 


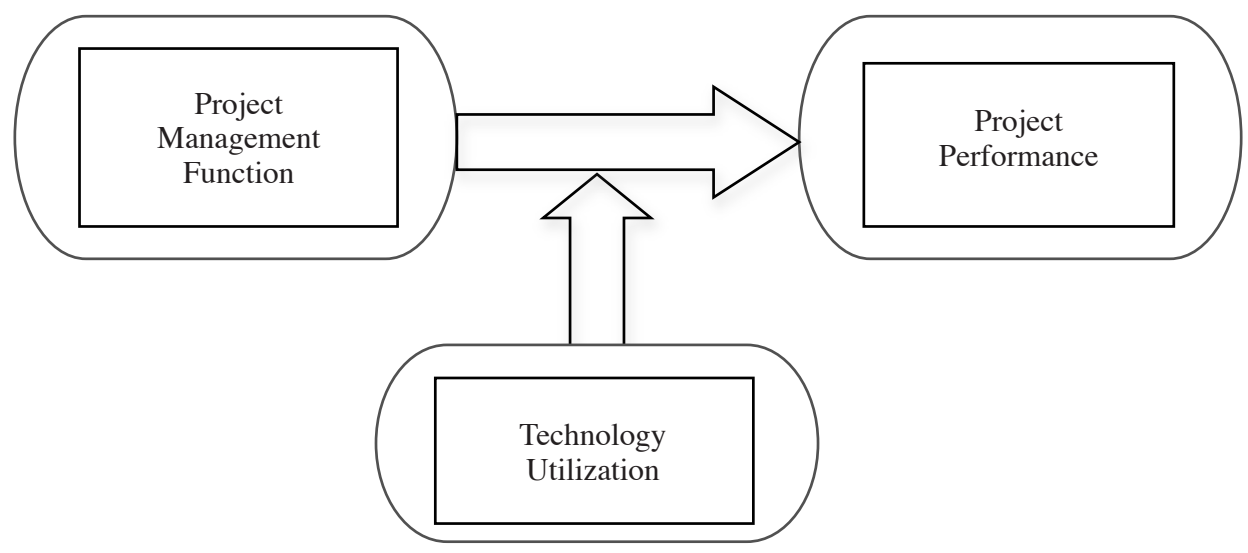

Figure 1. Conceptual Model of the Research.

\section{Research Design and Methodology}

This study used the questionnaire approach as a method of data collection. Data for this study was collected from the contractors, who represented their respective organization's construction in Aceh Province. A total of 800 questionnaires were distributed to construction organizations, with the hope that at least as much 50 per cent of the questionnaires will be collected back. Five hundred and sixteen questionnaires were returned, 48 questionnaires could not be used. Therefore, a total of 468 questionnaires represented a response rate of 58.5 per cent of the total number of questionnaires distributed and 20.05 per cent of the required sample size representing 2,334 of the construction organizations in Aceh Province. Stratified random sampling was used this study. The overall response could be considered to be a very high standard of data collection of about 20 per cent. In addition, the respondents were provided with self addressed envelopes to facilitate the return of the questionnaires.

In this research, the tool that was used was the SPSS version 17.0 software. In this study, partial correlation analysis were utilized from the SPSS software.

Table 1

Summary of Measurement Instruments Dimensions

\begin{tabular}{lllc}
\hline Variables & Dimension & Instrumentation & $\begin{array}{c}\text { No. of } \\
\text { items }\end{array}$ \\
\hline Project management & Project & Scope & 8 \\
function & integration & Time & Cost \\
& management & Quality &
\end{tabular}




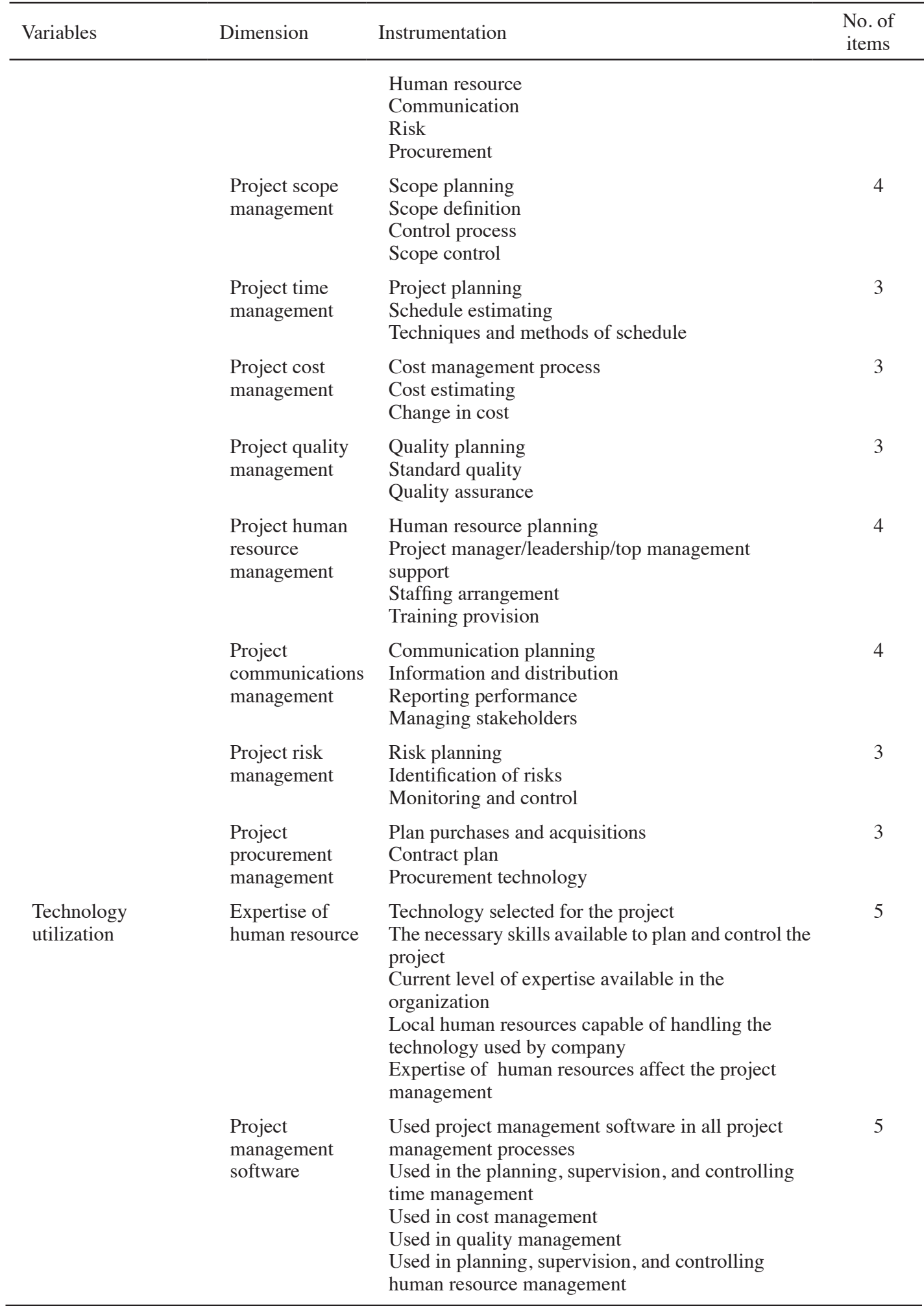




\begin{tabular}{|c|c|c|c|}
\hline Variables & Dimension & Instrumentation & $\begin{array}{l}\text { No. of } \\
\text { items }\end{array}$ \\
\hline & $\begin{array}{l}\text { Facility of } \\
\text { electronic tools }\end{array}$ & $\begin{array}{l}\text { The computer-based tools available for this project } \\
\text { Tools, techniques, and methods for planning and } \\
\text { controlling the project are adequate } \\
\text { The project management tool to provide sufficient } \\
\text { information } \\
\text { The facilities planning and management } \\
\text { administration was supportive of the } \\
\text { implementation } \\
\text { The facilities of electronic tools available in the } \\
\text { company have been successful }\end{array}$ & 5 \\
\hline \multirow[t]{4}{*}{ Project performance } & $\begin{array}{l}\text { Time } \\
\text { performance }\end{array}$ & $\begin{array}{l}\text { The schedule activities to be performed during the } \\
\text { project have been identified } \\
\text { Dependencies among all scheduled activities are } \\
\text { identified } \\
\text { Type and quantities of required resources are taken } \\
\text { into account } \\
\text { The number of work periods are estimated } \\
\text { Major activities are analysed } \\
\text { Project schedule changes are controlled properly }\end{array}$ & 6 \\
\hline & $\begin{array}{l}\text { Cost } \\
\text { performance }\end{array}$ & $\begin{array}{l}\text { Adequate in proper approximation of the costs of } \\
\text { the resources and activities } \\
\text { Project cost objectives were met } \\
\text { Last project was completed } \\
\text { Cost effectiveness of work } \\
\text { Performance on cost account }\end{array}$ & 5 \\
\hline & $\begin{array}{l}\text { Quality } \\
\text { performance }\end{array}$ & $\begin{array}{l}\text { The required quality standard has been identified } \\
\text { Some of the quality activities have been applied } \\
\text { Specific results of the project have been monitored } \\
\text { and identified } \\
\text { The change required to learn some things } \\
\text { The change required to design and select different } \\
\text { methods }\end{array}$ & 5 \\
\hline & $\begin{array}{l}\text { Stakeholder } \\
\text { satisfaction }\end{array}$ & $\begin{array}{l}\text { Contractor performs well in project time } \\
\text { Contractor performs well in project cost } \\
\text { Contractor performs well in project quality } \\
\text { Contractor performs well in line with technical } \\
\text { specifications } \\
\text { Contractor cooperates well with other contractors } \\
\text { Contractor cooperates well with owner, company } \\
\text { supervisor and designer } \\
\text { Contractor has externally developed a good team } \\
\text { with stakeholders } \\
\text { Project owner ensures construction supervision in } \\
\text { project performance }\end{array}$ & 8 \\
\hline
\end{tabular}

Table 1 shows lists of the summary of the measurement instruments dimensions of the independent variables, the moderating variables, and the dependent variables. Three main concepts formed the construct variable for this study: project management function as an independent variable $(\mathrm{X})$, technology utilization as a moderating variable $(\mathrm{M})$, and project performance as a dependent variable $(\mathrm{Y})$. All the constructs were multidimensional and 
incorporated multiple elements of measurement for each variable. Each variable used a five-point rating scale.

\section{Developed for this Research}

This section provides the hypotheses proposed for this study. The hypotheses are:

H1 : Technology utilization moderates the relationship between integration management and project performance.

H2 : Technology utilization moderates the relationship between scope management and project performance.

H3 : Technology utilization moderates the relationship between time management and project performance.

H4 : Technology utilization moderates the relationship between cost management and project performance.

H5 : Technology utilization moderates the relationship between quality management and project performance.

H6 : Technology utilization moderates the relationship between human resource management and project performance.

H7 : Technology utilization moderates the relationship between communication management and project performance.

H8 : Technology utilization moderates the relationship between risk management and project performance.

H9 : Technology utilization moderates the relationship between procurement management and project performance.

The above hypotheses postulate the relationship between the moderation of technology utilization and the dimensions of project management functions and project performance.

\section{The Results of the Analysis}

Construct validity is the extent to which the scale represents the concept being measured. Having established the construct validity of the project management function variables, these factors are the target of reliability testing to ensure a reliable measurement. The results of the reliability test for all the dimensions show that the Cronbach alpha coefficient was higher than 0.80 , thus providing support for discriminant validity. Table 2 below summarizes the result of the reliability test.

Partial correlation analysis were used to test the moderating effect of technology utilization on the relationship between project management functions and project performance. In this study, the significance level at $1 \%$ and $5 \%$ were used to detect the moderating effects of technology utilization on the relationship between project management function and project performance.

Tables 3, 4, and 5 show the results of correlation analysis between project management functions and project performance as moderated by technology utilization.

Most of the relationships between project management function and project performance moderated by technology utilization was significant at $\mathrm{p}<0.01$ and had a low positive correlation, except for the relationship between communication management and cost performance that was moderated by human resource expertise $(r=0.060 ; p=0.208)$; that was moderated by the software project management $(r=0.048 ; \mathrm{p}$ $=0.314$ ), and that was moderated by facility of electronic tools $(r=0.030 ; p=0.523)$. All three were not significant. The relationship between time management and stakeholder satisfaction, human resource management and stakeholder satisfaction that were moderated by the facility 
Table 2

Summary of Reliability Analysis

\begin{tabular}{llc}
\hline \multicolumn{1}{c}{ Variables } & \multicolumn{1}{c}{ Construct } & Cronbach alpha coefficient \\
\hline Project management function & Integration management & 0.969 \\
& Scope management & 0.954 \\
& Time management & 0.920 \\
& Cost management & 0.943 \\
& Quality management & 0.962 \\
& Human resource management & 0.959 \\
& Communication management & 0.957 \\
& Risk management & 0.955 \\
& Procurement management & 0.943 \\
Technology utilization & Human resource expertise & 0.906 \\
& Project management software & 0.934 \\
& Facility of electronic tools & 0.931 \\
& Time performance & 0.935 \\
Project performance & Cost performance & 0.905 \\
& Quality performance & 0.851 \\
& Stakeholder satisfaction & 0.926 \\
\hline & & \\
& &
\end{tabular}

Table 3

Correlation between Project Management Function and Project Performance Moderated by Human Resource Expertise

\begin{tabular}{lccccccccc}
\hline $\begin{array}{l}\text { Human } \\
\text { resource } \\
\text { expertise }\end{array}$ & $\begin{array}{c}\text { Integr. } \\
\text { Man. }\end{array}$ & $\begin{array}{l}\text { Scope } \\
\text { Man. }\end{array}$ & $\begin{array}{c}\text { Time } \\
\text { Man. }\end{array}$ & $\begin{array}{c}\text { Cost } \\
\text { Man. }\end{array}$ & $\begin{array}{c}\text { Qlty. } \\
\text { Man. }\end{array}$ & $\begin{array}{c}\text { HR } \\
\text { Man. }\end{array}$ & $\begin{array}{c}\text { Com. } \\
\text { Man. }\end{array}$ & $\begin{array}{c}\text { Risk } \\
\text { Man. }\end{array}$ & $\begin{array}{c}\text { Procur. } \\
\text { Man. }\end{array}$ \\
\hline $\begin{array}{l}\text { Time } \\
\text { performance }\end{array}$ & $0.412^{* *}$ & $0.371^{* *}$ & $0.305^{* *}$ & $0.328^{* *}$ & $0.212^{* *}$ & $0.319^{* *}$ & $0.180^{* *}$ & $0.283^{* *}$ & $0.263^{* *}$ \\
$\begin{array}{l}\text { Cost } \\
\text { performance }\end{array}$ & $0.343^{* *}$ & $0.265^{* *}$ & $0.225^{* *}$ & $0.228^{* *}$ & $0.148^{* *}$ & $0.240^{* *}$ & 0.060 & $0.134^{* *}$ & $0.188^{* *}$ \\
\hline
\end{tabular}

(continued) 


\begin{tabular}{lccccccccc}
\hline $\begin{array}{l}\text { Human } \\
\text { resource } \\
\text { expertise }\end{array}$ & $\begin{array}{c}\text { Integr. } \\
\text { Man. }\end{array}$ & $\begin{array}{c}\text { Scope } \\
\text { Man. }\end{array}$ & $\begin{array}{c}\text { Time } \\
\text { Man. }\end{array}$ & $\begin{array}{c}\text { Cost } \\
\text { Man. }\end{array}$ & $\begin{array}{c}\text { Qlty. } \\
\text { Man. }\end{array}$ & $\begin{array}{c}\text { HR } \\
\text { Man. }\end{array}$ & $\begin{array}{c}\text { Com. } \\
\text { Man. }\end{array}$ & $\begin{array}{c}\text { Risk } \\
\text { Man. }\end{array}$ & $\begin{array}{c}\text { Procur. } \\
\text { Man. }\end{array}$ \\
\hline $\begin{array}{l}\text { Quality } \\
\text { performance }\end{array}$ & $0.376^{* *}$ & $0.318^{* *}$ & $0.309^{* *}$ & $0.281^{* *}$ & $0.221^{* *}$ & $0.340^{* *}$ & $0.188^{* *}$ & $0.225^{* *}$ & $0.218^{* *}$ \\
$\begin{array}{l}\text { Stakeholder } \\
\text { satisfaction }\end{array}$ & $0.312^{* *}$ & $0.213^{* *}$ & $0.160^{* *}$ & $0.180^{* *}$ & $0.152^{* *}$ & $0.153^{* *}$ & $0.138^{* *}$ & $0.135^{* *}$ & $0.223^{* *}$ \\
\hline
\end{tabular}

** Significant correlation at level 0.01 (2-tailed)

* Significant correlation at level 0.05 (2-tailed)

\section{Table 4}

Correlation between Project Management Function and Project Performance Moderated by Project Management Software

\begin{tabular}{lccccccccc}
\hline $\begin{array}{l}\text { Project } \\
\text { management } \\
\text { software }\end{array}$ & $\begin{array}{c}\text { Integr. } \\
\text { Man. }\end{array}$ & $\begin{array}{c}\text { Scope } \\
\text { Man. }\end{array}$ & $\begin{array}{c}\text { Time } \\
\text { Man. }\end{array}$ & $\begin{array}{c}\text { Cost } \\
\text { Man. }\end{array}$ & $\begin{array}{c}\text { Qlty. } \\
\text { Man. }\end{array}$ & $\begin{array}{c}\text { HR } \\
\text { Man. }\end{array}$ & $\begin{array}{c}\text { Com. } \\
\text { Man. }\end{array}$ & $\begin{array}{c}\text { Risk } \\
\text { Man. }\end{array}$ & $\begin{array}{c}\text { Procur. } \\
\text { Man. }\end{array}$ \\
\hline $\begin{array}{l}\text { Time } \\
\text { performance }\end{array}$ & $0.384^{* *}$ & $0.347^{* *}$ & $0.286^{* *}$ & $0.295^{* *}$ & $0.172^{* *}$ & $0.289^{* *}$ & $0.130^{* *}$ & $0.259^{* *}$ & $0.232^{* *}$ \\
$\begin{array}{l}\text { Cost } \\
\text { performance }\end{array}$ & $0.345^{* *}$ & $0.277^{* *}$ & $0.237^{* *}$ & $0.231^{* *}$ & $0.147^{* *}$ & $0.242^{* *}$ & 0.048 & $0.144^{* *}$ & $0.196^{* *}$ \\
$\begin{array}{l}\text { Quality } \\
\text { performance }\end{array}$ & $0.362^{* *}$ & $0.308^{* *}$ & $0.302^{* *}$ & $0.264^{* *}$ & $0.201^{* *}$ & $0.327^{* *}$ & $0.161^{* *}$ & $0.213^{* *}$ & $0.202^{* *}$ \\
$\begin{array}{l}\text { Stakeholder } \\
\text { satisfaction }\end{array}$ & $0.307^{* *}$ & $0.222^{* * *}$ & $0.171^{* *}$ & $0.176^{* *}$ & $0.146^{* *}$ & $0.150^{* *}$ & $0.125^{*}$ & $0.144^{* *}$ & $0.229^{* *}$ \\
\hline
\end{tabular}

** Significant correlation at level 0.01 (2-tailed)

* Significant correlation at level 0.05 (2-tailed)

Table 5

Correlation between Project Management Function and Project Performance Moderated by Electronic Tool Facility

\begin{tabular}{lccccccccc}
\hline $\begin{array}{l}\text { Electronic } \\
\text { tool facility }\end{array}$ & $\begin{array}{c}\text { Integr. } \\
\text { Man. }\end{array}$ & $\begin{array}{c}\text { Scope } \\
\text { Man. }\end{array}$ & $\begin{array}{c}\text { Time } \\
\text { Man. }\end{array}$ & $\begin{array}{c}\text { Cost } \\
\text { Man. }\end{array}$ & $\begin{array}{c}\text { Qlty. } \\
\text { Man. }\end{array}$ & $\begin{array}{c}\text { HR } \\
\text { Man. }\end{array}$ & $\begin{array}{c}\text { Com. } \\
\text { Man. }\end{array}$ & $\begin{array}{c}\text { Risk } \\
\text { Man. }\end{array}$ & $\begin{array}{c}\text { Procur. } \\
\text { Man. }\end{array}$ \\
\hline $\begin{array}{l}\text { Time } \\
\text { performance }\end{array}$ & $0.356^{* *}$ & $0.322^{* *}$ & $0.277^{* *}$ & $0.296^{* *}$ & $0.211^{* *}$ & $0.297^{* *}$ & $0.173^{* *}$ & $0.302^{* *}$ & $0.267^{* *}$ \\
\hline
\end{tabular}




\begin{tabular}{lccccccccc}
\hline $\begin{array}{l}\text { Electronic } \\
\text { tool facility }\end{array}$ & $\begin{array}{c}\text { Integr. } \\
\text { Man. }\end{array}$ & $\begin{array}{c}\text { Scope } \\
\text { Man. }\end{array}$ & $\begin{array}{c}\text { Time } \\
\text { Man. }\end{array}$ & $\begin{array}{c}\text { Cost } \\
\text { Man. }\end{array}$ & $\begin{array}{c}\text { Qlty. } \\
\text { Man. }\end{array}$ & $\begin{array}{c}\text { HR } \\
\text { Man. }\end{array}$ & $\begin{array}{c}\text { Com. } \\
\text { Man. }\end{array}$ & $\begin{array}{c}\text { Risk } \\
\text { Man. }\end{array}$ & $\begin{array}{c}\text { Procur. } \\
\text { Man. }\end{array}$ \\
\hline $\begin{array}{l}\text { Cost } \\
\text { performance }\end{array}$ & $0.270^{* *}$ & $0.194^{* *}$ & $0.178^{* *}$ & $0.175^{* *}$ & $0.128^{* *}$ & $0.200^{* *}$ & 0.030 & $0.129^{* *}$ & $0.172^{* *}$ \\
\hline $\begin{array}{l}\text { Quality } \\
\text { performance }\end{array}$ & $0.327^{* *}$ & $0.273^{* *}$ & $0.282^{* *}$ & $0.249^{* *}$ & $0.215^{* *}$ & $0.318^{* *}$ & $0.179^{* *}$ & $0.231^{* *}$ & $0.214^{* *}$ \\
$\begin{array}{l}\text { Stakeholder } \\
\text { satisfaction }\end{array}$ & $0.239^{* *}$ & $0.148^{* *}$ & $0.118^{*}$ & $0.132^{* *}$ & $0.145^{* *}$ & $0.115^{*}$ & $0.126^{* *}$ & $0.148^{* *}$ & $0.225^{* *}$ \\
\hline
\end{tabular}

** Significant correlation at level 0.01 (2-tailed)

* Significant correlation at level 0.05 (2-tailed)

of electronic tools were significant at $\mathrm{p}<0.05$ and had a low positive correlate, $r=0.118$ and $r$ $=0.115$ respectively.

The variables of integration management and time performance which had the strongest correlation were moderated by the three variables of technology utilization: human resource expertise $(\mathrm{r}=0.412 ; \mathrm{p}<0.01)$; project management software $(\mathrm{r}=0.384 ; \mathrm{p}<0.01)$; and facility of electronic tools $(\mathrm{r}=0.356 ; \mathrm{p}<0.01)$.

- Partial correlation analysis was also made to the moderating effect of technology utilization as a whole on the relationship between the nine functions of project management and overall project performance. Table 6 shows the correlation between the project management functions and project performance that was moderated by overall technology utilization.

The result of partial correlation analysis of the moderating effect of technology utilization as a whole showed a significant and positive correlation, except for two of the nine variables of project management functions that were not significant, which were the relationship between quality management and overall project performance $(r=0.071 ; p=0.134)$, and the relationship between communication management and overall project performance $(\mathrm{r}=-0.001 ; \mathrm{p}=$ $0.987)$. The relationship between risk management and overall project performance indicated significance at $\mathrm{p}<0.05(\mathrm{r}=0094)$.

Table 6

Correlation between Project Management Function and Project Performance Moderated by Overall Technology Utilization

\begin{tabular}{lccccccccc}
\hline $\begin{array}{l}\text { Technology } \\
\text { utilization }\end{array}$ & $\begin{array}{c}\text { Integr. } \\
\text { Man. }\end{array}$ & $\begin{array}{c}\text { Scope } \\
\text { Man. }\end{array}$ & $\begin{array}{c}\text { Time } \\
\text { Man. }\end{array}$ & $\begin{array}{c}\text { Cost } \\
\text { Man. }\end{array}$ & $\begin{array}{c}\text { Qlty. } \\
\text { Man. }\end{array}$ & $\begin{array}{c}\text { HR } \\
\text { Man. }\end{array}$ & $\begin{array}{c}\text { Com. } \\
\text { Man. }\end{array}$ & $\begin{array}{c}\text { Risk } \\
\text { Man. }\end{array}$ & $\begin{array}{c}\text { Procur } \\
\text { Man. }\end{array}$ \\
\hline $\begin{array}{l}\text { Project } \\
\text { performance }\end{array}$ & $0.343^{* *}$ & $0.199^{* *}$ & $0.174^{* *}$ & $0.155^{* *}$ & 0.071 & $0.197^{* *}$ & -0.001 & $0.094^{*}$ & $0.126^{* *}$ \\
$\begin{array}{l}\text { Significance } \\
(2-\text { tailed })\end{array}$ & 0.000 & 0.000 & 0.000 & 0.001 & 0.134 & 0.000 & 0.987 & 0.049 & 0.008 \\
\hline
\end{tabular}

Significant correlation at level 0.01 (2-tailed)

* Significant correlation at level 0.05 (2-tailed) 
The moderating effect of technology utilization showed the strongest correlation on the relationship between integration management and overall project performance $(\mathrm{r}=0.343 ;<\mathrm{p} 0.01)$. Partial correlation analysis results were supported by overall technology utilization as a moderation on the relationship between the seven variables of project management functions and overall project performance.

Partial correlation analysis were conducted to determine the moderating effect of technology utilization on the relationship between project management functions and project performance. In general, the results of partial correlation analysis showed that technology utilization moderated the relationship between seven of the nine functions of project management and overall project performance. Individually, these three variables of technology utilization did not moderate the relationship between communication management and cost performance.

\section{Discussion and Conclusion}

\section{Discussion}

This study investigated the potential impact of technology utilization on the relationship between the project management functions and project performance.

In particular, three elements of technology utilization (human resource expertise, project management software, and electronic tools facility) that acted as a moderator examined the effects that might arise in the relationship between the variables of project management functions and project performance variables.

The results of the reliability test for all the dimensions showed that the Cronbach alpha coefficients were above 0.8 , indicating that the measure processes had high reliability.

Overall, most of the moderating technology utilization elements correlated positively with the project management function variables and project performance, with the exception of the relationship between quality management and project performance, and communication management and project performance. Partial correlation analysis results showed that technology utilization moderated the relationship between seven of the nine functions of project management and project performance which were the relationship between integration management, scope management, time management, cost management, human resource management, risk management, procurement management with overall project performance.

The results of the correlation analysis showed that the majority of human resource expertise had relationships between the project management function variables and project performance (time performance, cost performance, quality performance, stakeholder satisfaction) and were positively correlated with the level of moderate correlation. Besides the relationship between communication management and cost performance, human resource expertise did not show any relationship between both of these variables. The strongest correlation moderating human resources expertise was the relationship on integration management and time performance.

Most dimensions of the project management software also showed significant correlation with moderate levels between all dimensions of project management functions and dimensions of project performance, except between communication management and cost performance where there was no relationship. The relationship between integration management and time performance had the strongest correlation by project management software.

Further, dimensional electronic tools facilities were generally significant and the relationship between all dimensions of project management functions and dimensions of project performance were significant, except the relationship between communication management and cost of performance. The strongest correlation was the 
relationship between integration management and time performance.

In short, the three variables of technology utilization had no relationship between communication management and cost performance. Human resource expertise, project management software, and electronic tools facility, the relationship between eight of the nine project management functions on the dimensions of time performance, quality performance, and stakeholder satisfaction.

The moderating influence of human resource expertise in the variable of the project performance was also consistent with the findings of Pinto and Prescott (1988); Greer (1999); Poon and Wagner (2001); Caldeira and Ward (2002); and Fortune and White (2006).

The influence of the moderating project management software in the variable of project performance was also consistent with previous literature Keen (1991); Haeckel and Nolan (1993); Pollack and Liberatore (1998); Hoch et al. (2000); Rose and Suhanic (2001); Lusthaus et al. (2002); Jones (2004); Dawood and Mallasi (2006); Thomas and Fernandez (2008).

The findings indicate that the facility of electronic tools contribute the strongest moderating relationship between the project management functions and project performance. This study showed that the organization sought to enhance the performance of the project by providing support with higher electronic tools, such as computers to help integrate the project management system (Rose \& Suhanic, 2001). Griffis et al. (1995), and Goodrum and Haas (2002) also found that the effect of various electronic tools increased the productivity of the construction on project performance.

In general, the results of the moderating effects of technology utilization on the relationship between the variables of project management functions and variables of the project performance. This is in a agreement with the literature which showed that good project management functions and technology utilization should complement each other to achieve higher projects (Project Management Institute, 2004). Evidence from this study showed the importance of technology utilization to the construction organizations.

The results of this study have implications for practitioners and academics. The implications also serve as a backup to the contractors and as a contribution to the knowledge of the academic experts. For academics, more research needs to be done to build relationships to benefit the overall project management. The practitioners, in the search for the benefits of the project, should not depend on specific management techniques, but some important management techniques for organizational survival and project performance.

\section{Conclusion}

The results showed the partial support for the influence between the project management functions relationships and project performance. Therefore, the role that the two approaches complement each other should be recognized.

Findings of this study in the moderating effects of technology utilization have a number of important implications for project management of construction organizations. The key management implications of this study was between the project management functions and technology utilization to achieve greater project performance. This study showed that there is significant interaction between several dimensions of project management functions and technology utilization dimensions toward project performance dimensions. Construction organizations must be registered on this interaction to be able to increase the performance of the projects.

The findings from this study contribute to the empirical study of the moderating influence of technology utilization on the relationship between the project management functions and project 
performance in Aceh Province. Thus, this study adds to the knowledge available from the studies of project management that a combination of influence from project management functions and technology utilization has an impact on project performance. This research further contributes to the PMBOK and encourages it to study the individual effect and dimensions of technology utilization toward project performance variables. (See Appendixes in the following pages).

\section{References}

Abednego, M. P., \& Ogunlana, S. O. (2006). Good project governance for proper risk allocation in public-private partnerships in Indonesia. International Journal of Project Management, 24, 22-634.

Anantatmula, V.S. (2008). The role of technology in the project manager performance model. Project Management Journal, 39, 34-48.

Archibald, R. D. (1992). Managing hightechnology programs and projects, (2nd ed.). Wiley, Chichester.

Atkinson, R. (1999). Project management: Cost, time and quality, two best guesses and a phenomenon, its time to accept other success criteria. International Journal of Project Management, 17(6), 337-342.

Baccarini, D. (1999). The logical framework method for defining project success. Project Management Journal, 30(4), 25-32.

Back, W. E., \& Bell, L. C. (1994). Quantifying benefits of electronic technology applied to bulk materials management. Houston: Construction Industry Action Group.

Baker, B. N., Murphy, D. C., \& Fisher, D. (1988). Factors affecting project success-project management handbook. New York: Van Nostrand Reinhold Co.

Bay, F. A., Skitmore, M., \& Susilawati. (2005). Maturity level of project management. Dimensi Teknik Sipil. Jurnal Keilmuwan dan Penerapan Teknik Sipil, 7(2), 8189, Petra Christian University Research Centre.
Belassi, W., \& Tukel, O. I. (1996). A new framework for determining critical success/ failure factors in projects. International Journal of Project Management, 14(3), 141-151.

Belout, A., \& Gauvreau, C. (2004). Factors influencing project success : The impact of human resource management. International Journal of Project Management, 22, 1-11.

Bower, D., Ashby, G., Gerald, K., \& Smyk, W. (2002). Incentive mechanisms for project success. Journal of Management Engineering, 18(1), 37-43.

Bryde, J. D., \& Brown, D. (2004). The influence of a project performance measurement system on the success of a contract for maintaining motorways and trunk roads. Project Management Institute, 35(4), 57-65.

Caldeira, M. M., \& Ward, J. M. (2002). Understanding the successful adoption and use of IS/IT in SMEs: An explanation from Portuguese manufacturing industries. Information Systems Journal, 12, 121-152.

CERF. (1997). Commercializing infrastructure technologies, civil engineering research foundation. CERF Report \#97-5028, USA.

Coakes, S. J., Steed, L., \& Ong, C. (2009). SPSS Version 16.0 for Windows - analysis without anguish. Milton: John Wiley \& Sons Australia, Ltd.

Cooke-Davies, T. (2002). The real success factors on projects. International Journal of Project Management, 20(3), 185-190.

Cokins, G. (2006). Performance management. In Adkins, T., Case studies in performance management: A guide from the experts. John Wiley and Sons, New Jersey.

Crawford, L. (2000). Profiling the competent project manager. Proceedings of PMI Research Conference. Paris, France.

Crawford, L., Pollack, J., \& England, D. (2005). Uncovering the trends in project management: Journal emphases over the last 10 years. International Journal of Project Management, 24, 175-184.

Dawood, N., \& Mallasi, Z. (2006). Construction workspace planning: Assignment and 
analysis utilizing 4D visualization technologies. Journal of Computer-Aided Civil and Infrastructure Engineering, 21, 498-513.

Diallo, A., \& Thuillier, D. (2005). The success of international development projects, trust and communication: An African perspective. International Journal of Project Management, 23, 237-252.

Dvir, D., Raz, T., \& Shenhar, A. J. (2003). An empirical analysis of the relationship between project planning and project success. International Journal of Project Management, 21(2), 89-95.

Dvir, D., Sadeh, A., \& Pines, A. M. (2006). Projects and project managers: The relationship between project managers' personality, project types, and project success. Project Management Institute, 37(5), 36-48.

Fortune, J., \& White, D. (2006). Framing of project critical success factors by a systems model. International Journal of Project Management, 24(1), 53-65.

Freeman, M., \& Beale, P. (1992). Measuring project success. Project Management Journal, 23(1), 8-17.

Frese, R. (2003). Project success and failure: What is success, what is failure, and how can you improve your odds for success? Journal of Knowledge Management Practice.

Goodrum, P. M., \& Haas, C. T. (2002). Partial factor productivity and equipment technology change at activity level in US construction industry. Journal of Construction Engineering Management, 128(6), 463-472.

Griffis, F. H., Hogan, D. B., \& Li, W. (1995). An analysis of the impacts of using three dimensional computer models in the management of construction. Construction Industry Institute (CII), Research Report 106-11, Austin, TX, USA.

Greer, M. (1999). 14 key principles for project management success. San Francisco: Jossey-Bass.
Haeckel, S. H., \& Nolan, R. (1993). Managing by wire. Harvard Business Review, 71, 122-132.

Hartman, F., \& Ashrafi, R. A. (2002). Project management in the information systems and information technologies industries. Project Management Journal, 33, 5-15.

Hatush, Z., \& Skitmore, M. (1997). Evaluating contractor prequalification data: Selection criteria and project success factors. Construction Management and Economics Journal, 15(2), 129-147.

Henry.(2008). Metoda estimasi waktu penyelesaian konstruksi bangunan. (Theses from Civil Engineering). Indonesia: Institut Teknologi Bandung.

Hoch, D. J., Roeding, C. R., Purkert, G., \& Lindner, S. K. (2000). Secrets of software success. Boston MA: Harvard Business School Press.

Hughes, S. W., Tippett, D. D., \& Thomas, W. K. (2004). Measuring project success in the construction industry. Engineering Management Journal, 16, 3.

Jaselskis, E. J., \& Ashley, D. B. (1991). Optimal allocation of project management resources for achieving success. Journal of Construction Engineering and Management, 117(2), 321-340.

Jha, K. N., \& Iyer, K. C. (2007). Commitment, coordination, competence and the iron triangle. International Journal of Project Management, 2, 527-540.

Jiang, J. J. (2001). Software project risks and development focus. Project Management Journal, 32(1), 4-9.

Jones, C. (2004). Software project management practices: Failure versus success. Software Productivity Research LLC.

Jugdev, K., \& Muller, R. (2005). A retrospective look at our evolving understanding of project success. Project Management Institute, 36(4),19-31.

Keen, P. W. (1991). Shaping the future. Boston: Harvard Business School Press.

Kerzner, H. (2000). Applied project management - Best practices on implementation. New York: John Wiley \& Sons. 
Khang, D. B., \& Moe, T. L. (2008). Success criteria and factors for international development projects: A life-cycle-based framework. Project Management Journal, 39(1), 72-84.

Landaeta, R. E. (2008). Evaluating benefits and challenges of knowledge transfer across projects. Engineering Management Journal, 20, 1.

Lembaga Pengusaha Jasa Konstruksi Indonesia. (2009). Statistik Badan Usaha Tahun 2009. Indonesia: LPJK.

Levy, S. M. (2000). Project management in construction. New York: McGraw-Hill.

Lim, C. S., \& Mohamed, M. Z. (1999). Criteria of project success: An exploratory reexamination. International Journal of Project Management, 17(4), 243-248.

Lim, E. H., \& Ling, F. Y. Y. (2002). Model for predicting client's contribution to project success. Journal of Engineering Construction Architect Management, 9 (5/6), 388-395.

Ling, F. Y.Y., Low, S.P., Wang, S. Q., \& Lim, H. H. (2009). Key project management practices affecting Singaporean firms' project performance in China. International Journal of Project Management, 59-71.

Liu, A. N. N., \& Walker, A. (1998). Evaluation of project outcomes. Construction Management and Economics, 16, 209-219.

Lusthaus, C., Adrien, M.H., Anderson, G., Carden, F., \& Montalván. (2002). Organizational assessment: A framework for improving performance. Inter-American Development Bank, Washington, D. C., Ottawa, Canada: International Development Research Centre.

Meng, X. (2012). The effect of relationship management on project performance in construction. International Journal of Project Management, 30(2), 188-198.

Morris, P. W. G., \& Hough, G. H. (1986). The preconditions of success and failures in major projects. Technical Paper, No. 3, Oxford: Major Project Association.
Morris, P. W. G., \& Hough, G. H. (1987). The anatomy of major projects: A study of the reality of project management. New York: John Wiley \& Sons.

Müller, R., \& Turner, R. (2007). The influence of project managers on project success criteria and project success by type of project. European Management Journal, 25(4), 298-309.

Munns, A. K. (1995). Potential influence of trust on the successful completion of a project. International Journal of Project Management, 13(1), 19-24.

Ofori, G. (1991). Programmes for improving the performance of contracting firms in developing countries: A review of approaches and appropriate options. Journal of Construction Management Economy, 9, 19-38.

Ogunlana, S. O., Promkuntong, K., \& Jearkjirm, V. (1996). Construction delays in a fastgrowing economy: Comparing Thailand with other economies. International Journal of Project Management, 14(1), 37-45.

Pinto, J. K., \& Prescott, J. E. (1988). Variations in critical success factors over stages in the project life cycle. Journal of Management, 14(1), 5-18.

Pinto, J. K., \& Slevin, D. P. (1988). Project success definitions and measurement techniques. Project Management Journal, 19(3), 6773.

Pinto, J. K., \& Slevin, D. P. (1989). Critical success factors in R \& D projects. Technology Management Journal, 31-35.

Pollack, J. B., \& Liberatore, M. J. (1998). Project management software usage patterns and suggested research directions for future developments. Project Management Journal, 29(2), 19-28.

Poon, P., \& Wagner, C. (2001). Critical success factors revisited: Success and failure cases of information systems for senior executives. Decision Support System, 30(4), 393-418. 
Project Management Institute. (1996). A guide to the project management body of knowledge. PMBOK Guide, Project Management Institute. Newtown Square, PA: PMI Publishing.

Project Management Institute. (2000). A guide to the project management body of knowledge. PMBOK Guide, 2000 Edition. Newtown Square, PA: PMI Publishing.

Qureshi, T. M., Warraich, A. S., \& Hijazi, S. T. (2009). Significance of project management performance assessment (PMPA) model. International Journal of Project Management, 27, 569-574.

Rasli, A., Madjid, M. Z., \& Asmi, A. (2004). Factors that influence implitation of knowledge management and information technology infrastructure to support project performance in the construction industry. International Business Management Conference, 62-70. Malaysia: Universiti Tenaga Nasional.

Reich, B. H., \& Wee, S. Y. (2006). Searching for knowledge in the PMBOK guide. Project Management Institute, 37(2), 11-26.

Reza, F. (2006). Sebuah agenda rakyat? Bantuan pasca tsunami di Aceh. Eye On Aceh. Retrieved from www.acheh-eye.org.

Rose, K. H., \& Suhanic, G. (2001). Computer - aided project management. Project Management Journal, 32(2), 60-61.

Sadeh, A., Dvir, D., \& Shenhar, A. (2000). The role of contract type in the success of $\mathrm{R} \& \mathrm{D}$ defence projects under increasing uncertainty. Project Management Journal, 31(3), 14-21.

Shenhar, A. J. (2004). Strategic project leadership: Toward a strategic approach to project management. $R \&$ D Management Journal, 34(5), 569-578.

Shenhar, A. J., \& Dvir, D. (2007). Project management research: The challenge and opportunity. Project Management Institute, 38(2), 93-99.

Shenhar, A. J., Levy, O., \& Dvir, D. (1997). Mapping the dimensions of project success. Project Management Journal, 28(2), 5-13.
Soeharto, I. (1998). Manajemen proyek (dari konseptual sampai operasional), Jilid 1. Jakarta, Indonesia: Erlangga.

Soemardi, B. W., Wirahadikusumah, R. D., \& Abduh, M. (2007). Construction project planning and control practices in Indonesia. Faculty of Civil and Enviromental Engineering, Institut Teknologi Bandung, Bandung, Indonesia: Ganesha 10.

Thomas, G., \& Fernández, W. (2008). Success in IT projects: A matter of definition? International Journal of Project Management, 26, 733-742.

Thomas, S. R., Tucker, R. L., \& Kelly, W. R. (1998). Critical communications variables. Journal of Construction Engineering Management, 124(1), 58-66.

Toor, S. R., \& Ogunlana, S. O. (2008). Critical COMs of success in large-scale construction projects: Evidence from Thailand construction industry. International Journal of Project Management, 26, 420430.

Toor, S. R., \& Ogunlana, S. O. (2010). Beyond the 'Iron Triangle': Stakeholder perception of key performance indicators (KPIs) for large - scale public sector development projects. International Journal of Project Management, 28(3), 228-236.

Turner, J. R. (1993). The handbook of projectbased management. New York: McGrawHill.

Turner, J. R. (2004). Five necessary conditions for project success. International Journal of Project Management, 22, 349-350.

Turner, J. R. (2009). The handbook of projectbased management-leading strategic change in organizations (3rd ed.). New York: McGraw-Hill.

Turner, J. R., \& Müller, R. (2003). One the nature of the project as a temporary organization. International Journal of Project Management, 21(1), 1-8.

Walker, D. H. T. (1995). An investigation into construction time performance. Construction Management and Economics, 13(3), 263-274. 
Walker, D. H. T. (1996). The contribution of the construction management team to good construction time performance An Australian experience. Journal of Construction Procurement, 2(2), 4-18.

Wang, X., \& Huang, J. (2006). The relationships between key stakeholders' project performance and project success: Perceptions of Chinese construction supervising engineers. International Journal of Project Management, 24, 253260.

Wateridge, J. (1998). How can IT/IS projects be measured for success? International Journal of Project Management, 16(1), 59-63.

Wesli. (2007). Menelusuri kegagalan proyek konstruksi. Hidup bersama risiko bencana, Topik: Rekonstruksi dan rehabilitasi Aceh, Indonesia.

Westerveld, E. (2003). The project excellence model: Linking success criteria and critical success factors. International Journal of Project Management, 21, 411-418.
White, M. A., \& Bruton, G. D. (2007). The management of technology and innovation: A strategic approach. Journal of Engineering and Technology Management, 24, 395-399.

Wood, J. R. (2008). Effective project management. Health Facilities Management, 21, 6.

Wueliner, W. W. (1990). Project performance evaluation checklist for consulting engineers. Journal of Management in Engineering, 6(3), 270-281.

Yang, L. R., O'Connor, J. T., \& Wang, C. C. (2006). Technology utilization on different sizes of projects and associated impacts on composite project success. International Journal of Project Management, 24, 96105.

Yang, J., Shen, G. O., Ho, M., Drew, D. S., \& Xue, X. (2011).Complexities in managing mega construction projects. International Journal of Project Management, 29(7), 900-910. 
Malaysian Management Journal Vol. 17, 77-113 (2013)

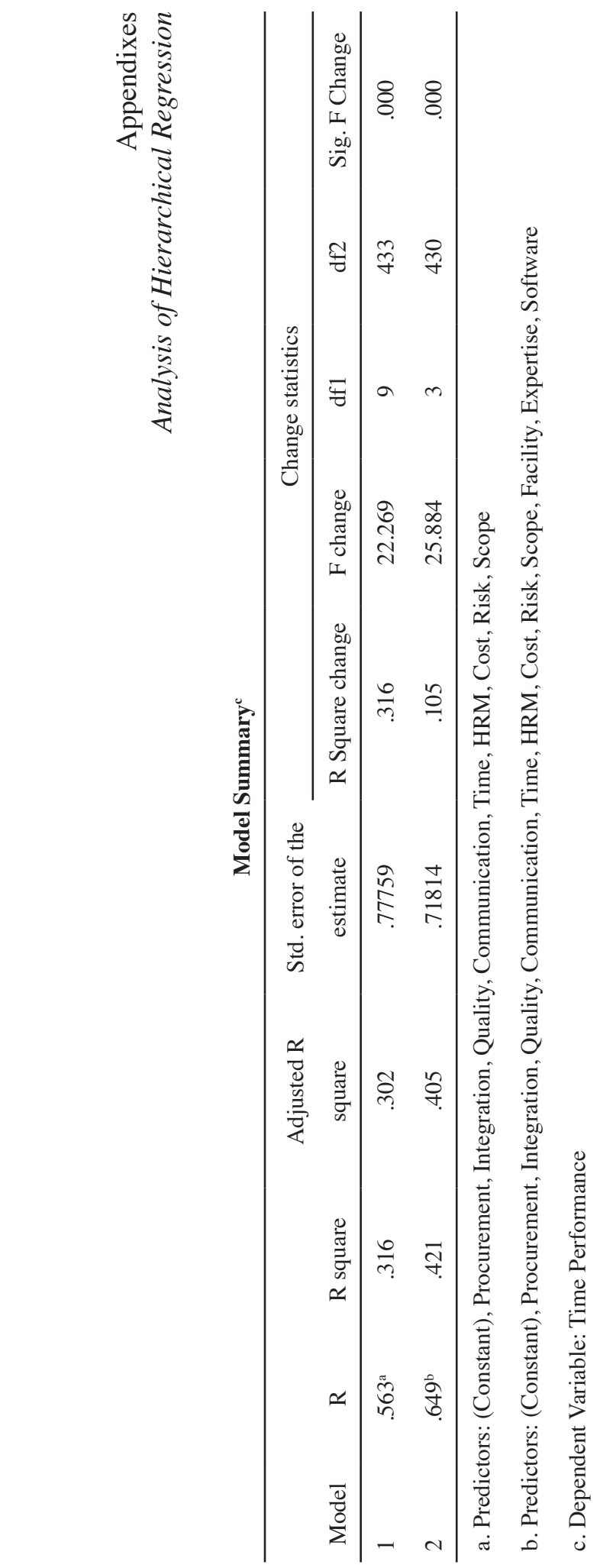




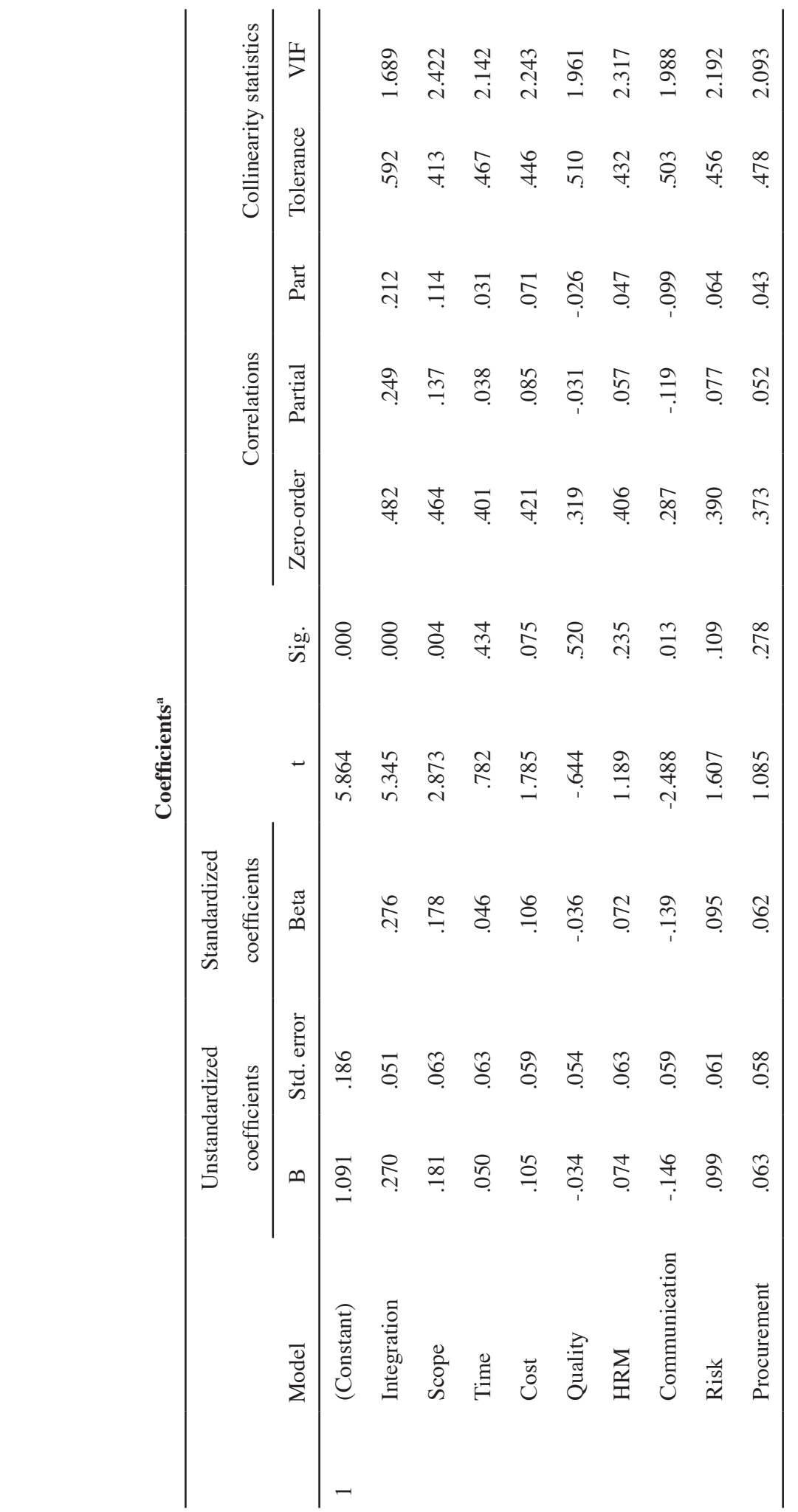




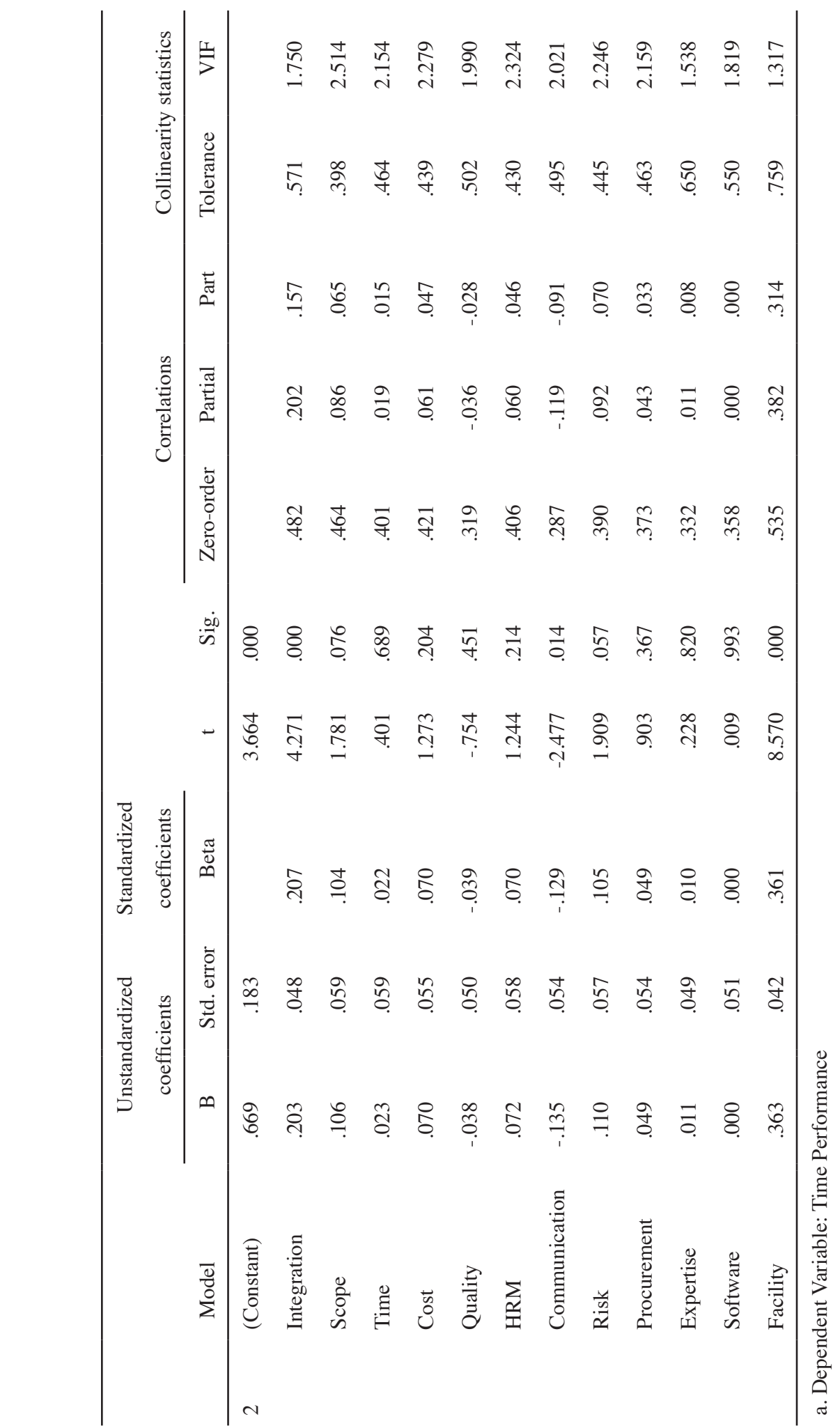


Malaysian Management Journal Vol. 17,77-113 (2013)

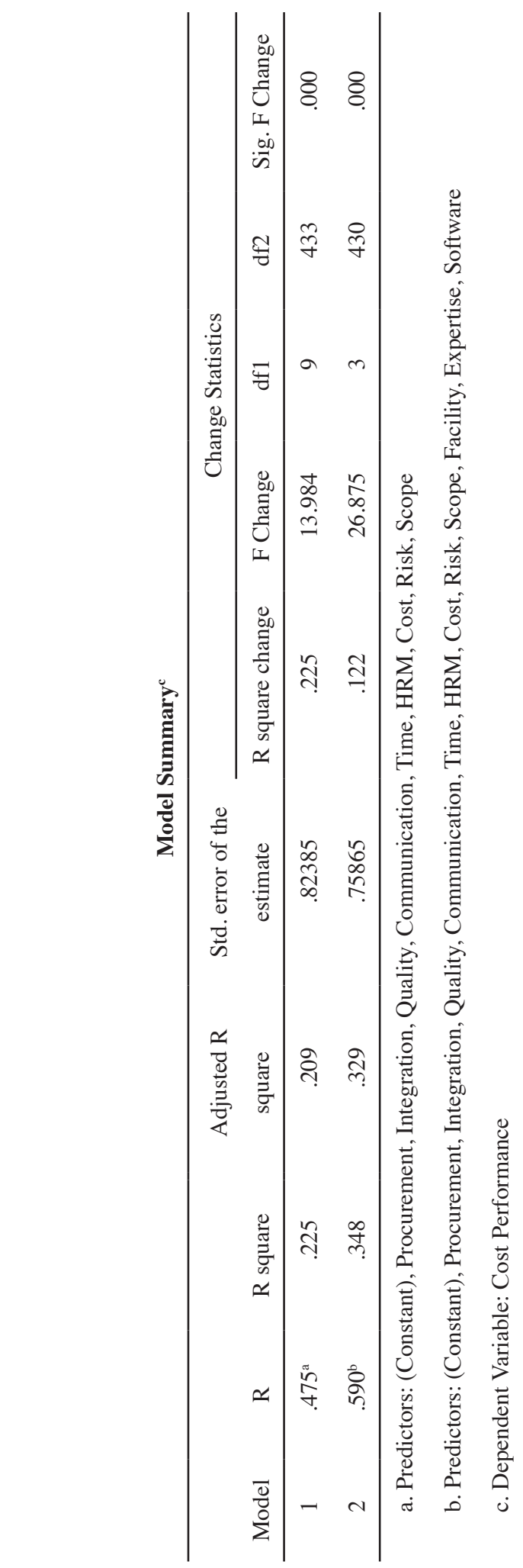




(1)


Malaysian Management Journal Vol. 17, 77-113 (2013)

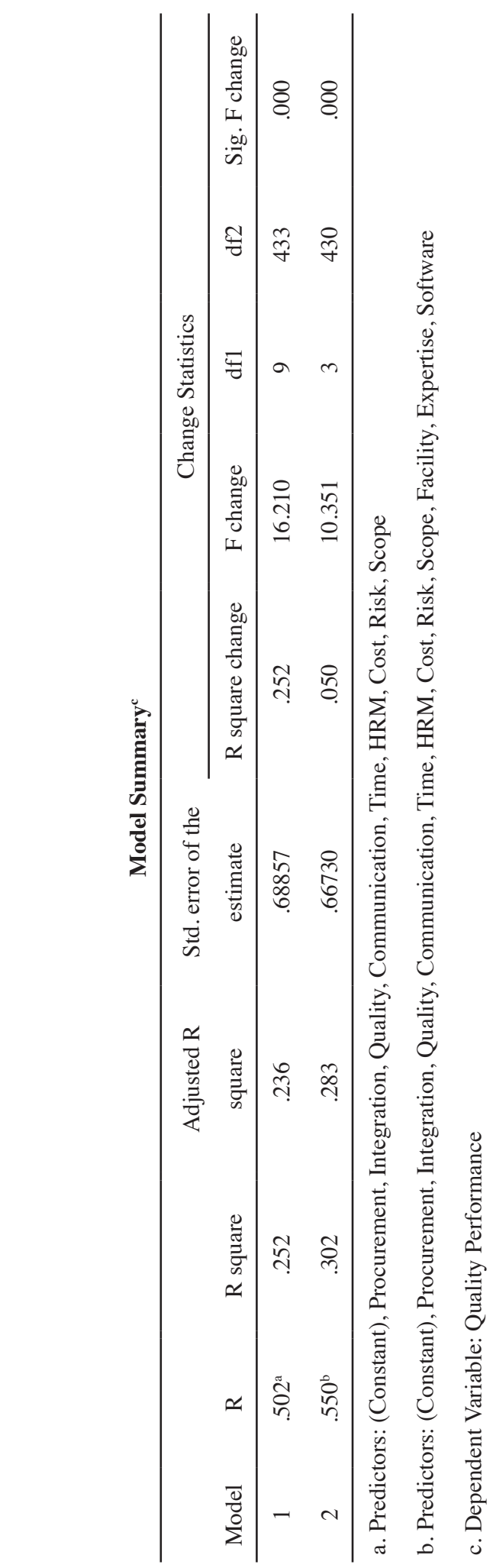




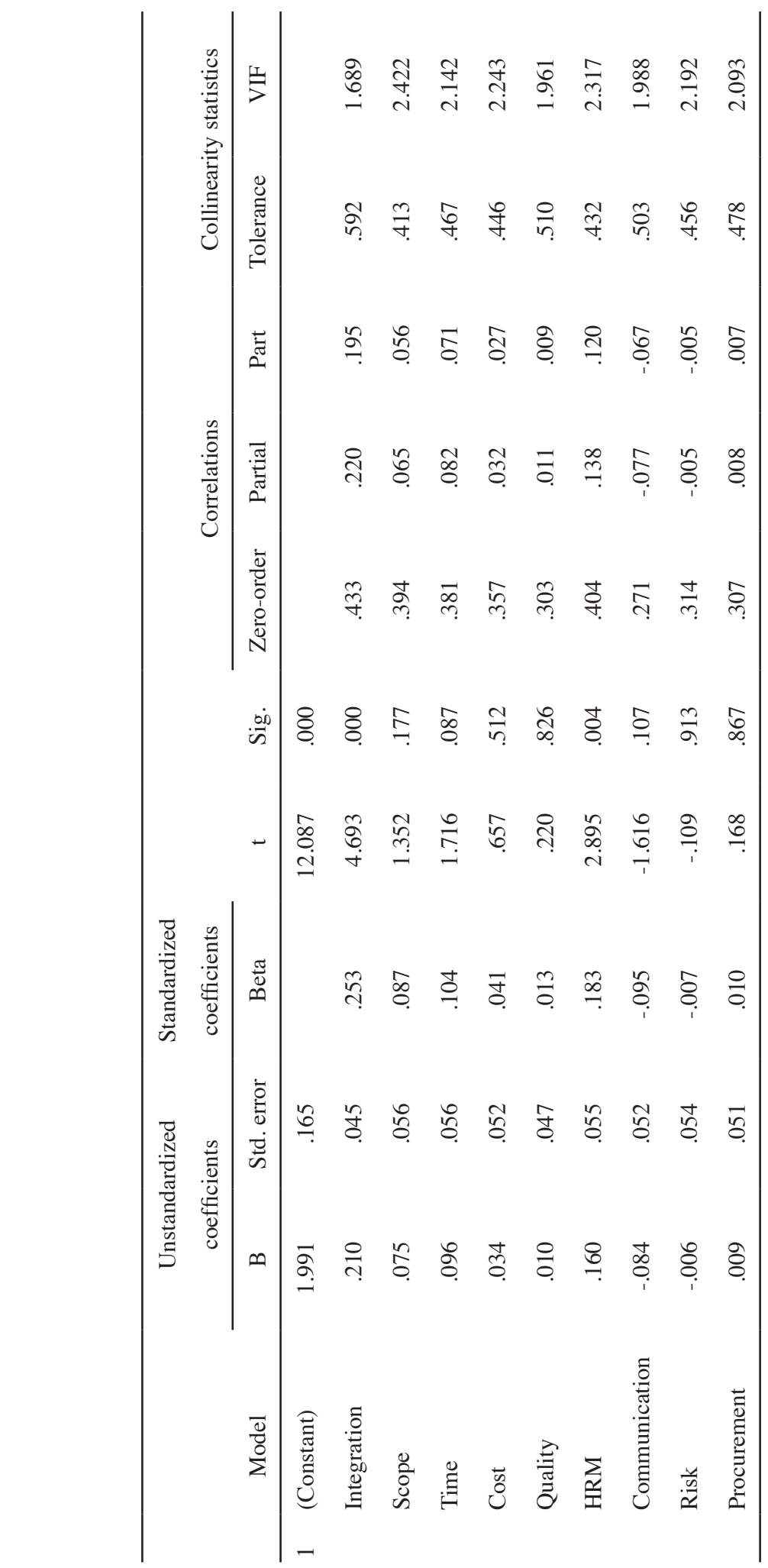


Malaysian Management Journal Vol. 17,77-113 (2013)

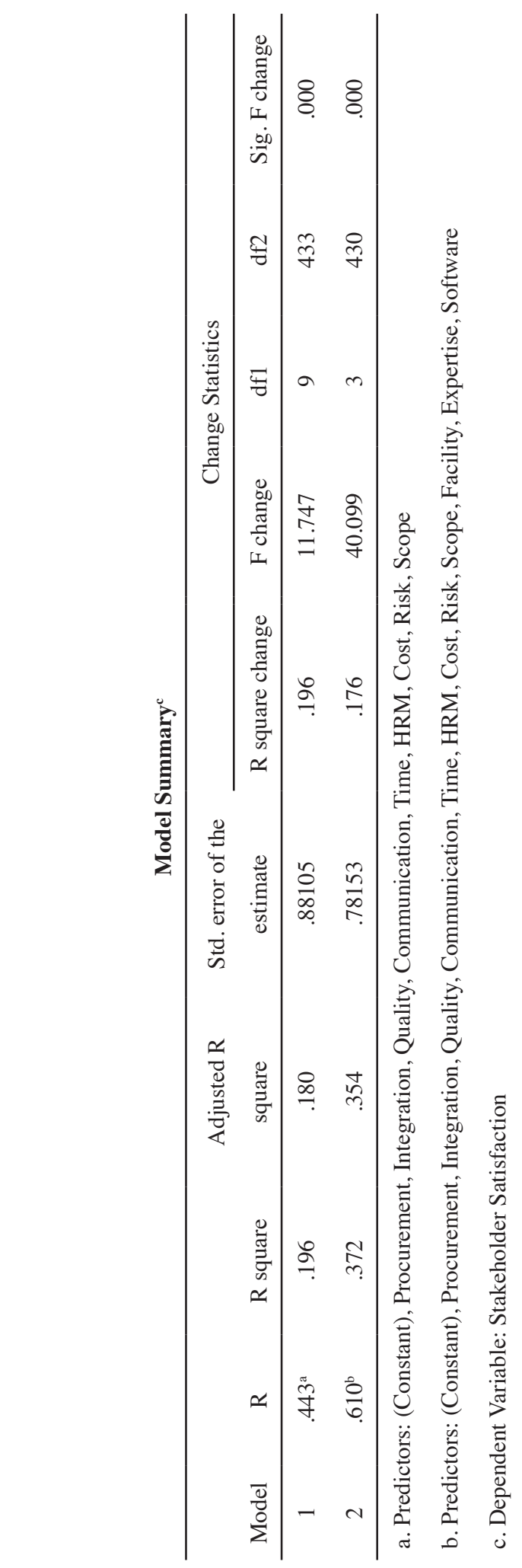




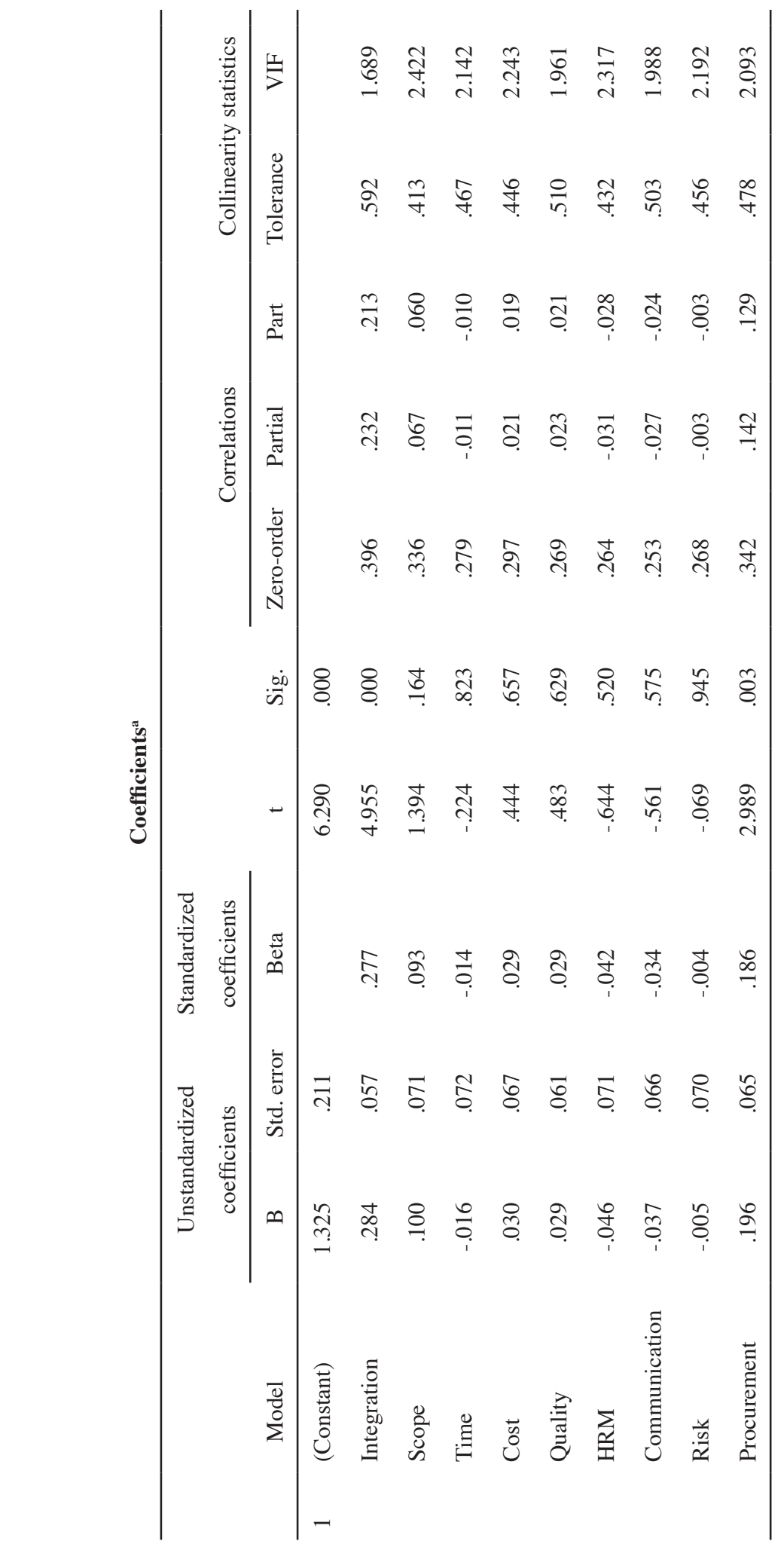




(1)


Malaysian Management Journal Vol. 17, 77-113 (2013)

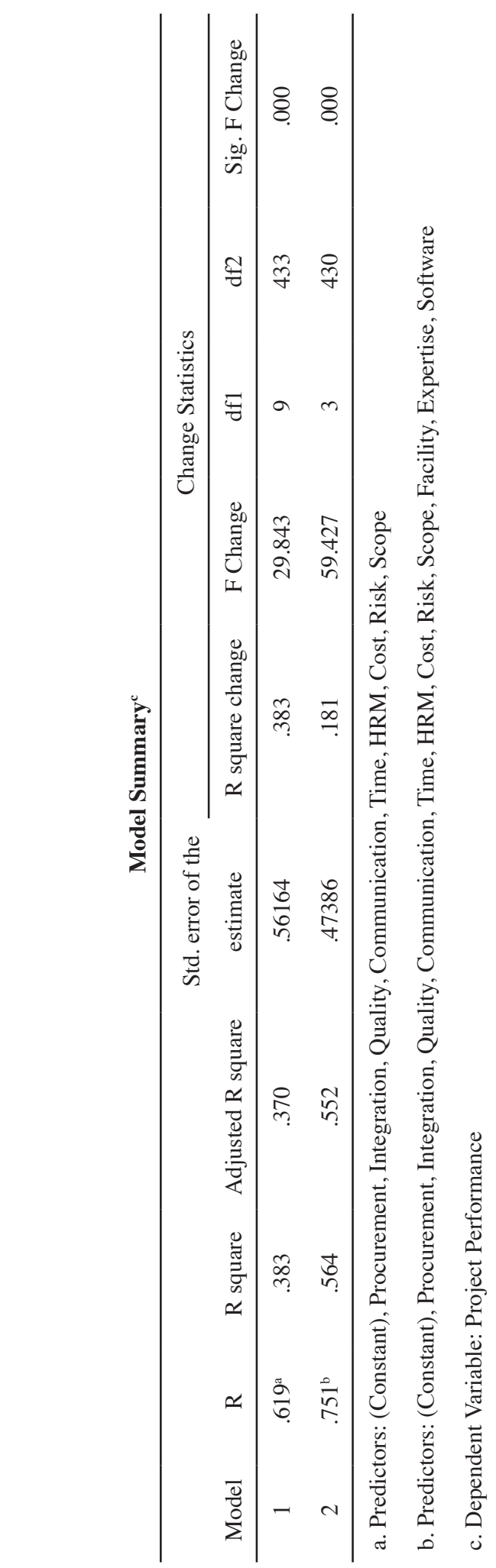




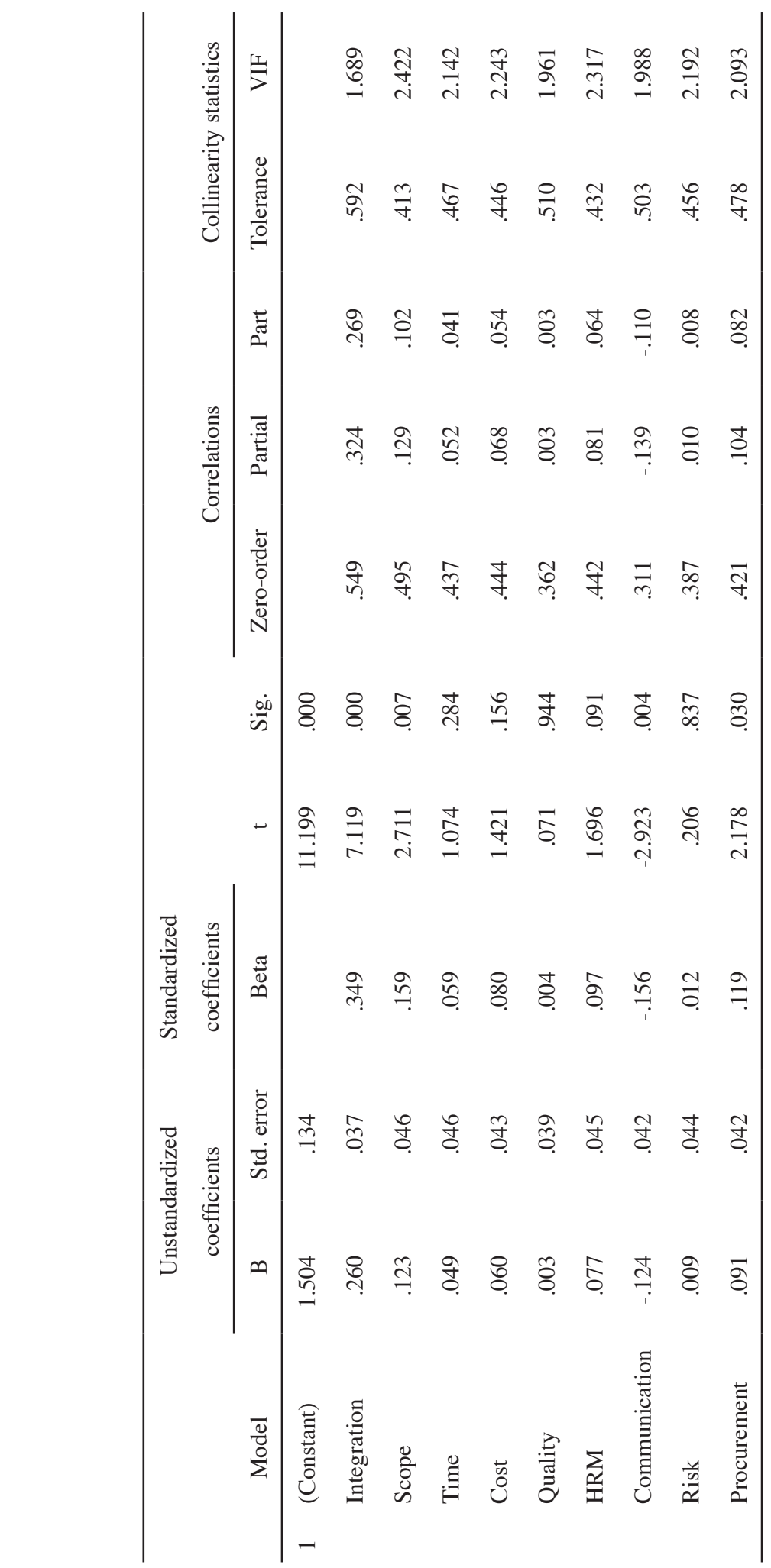




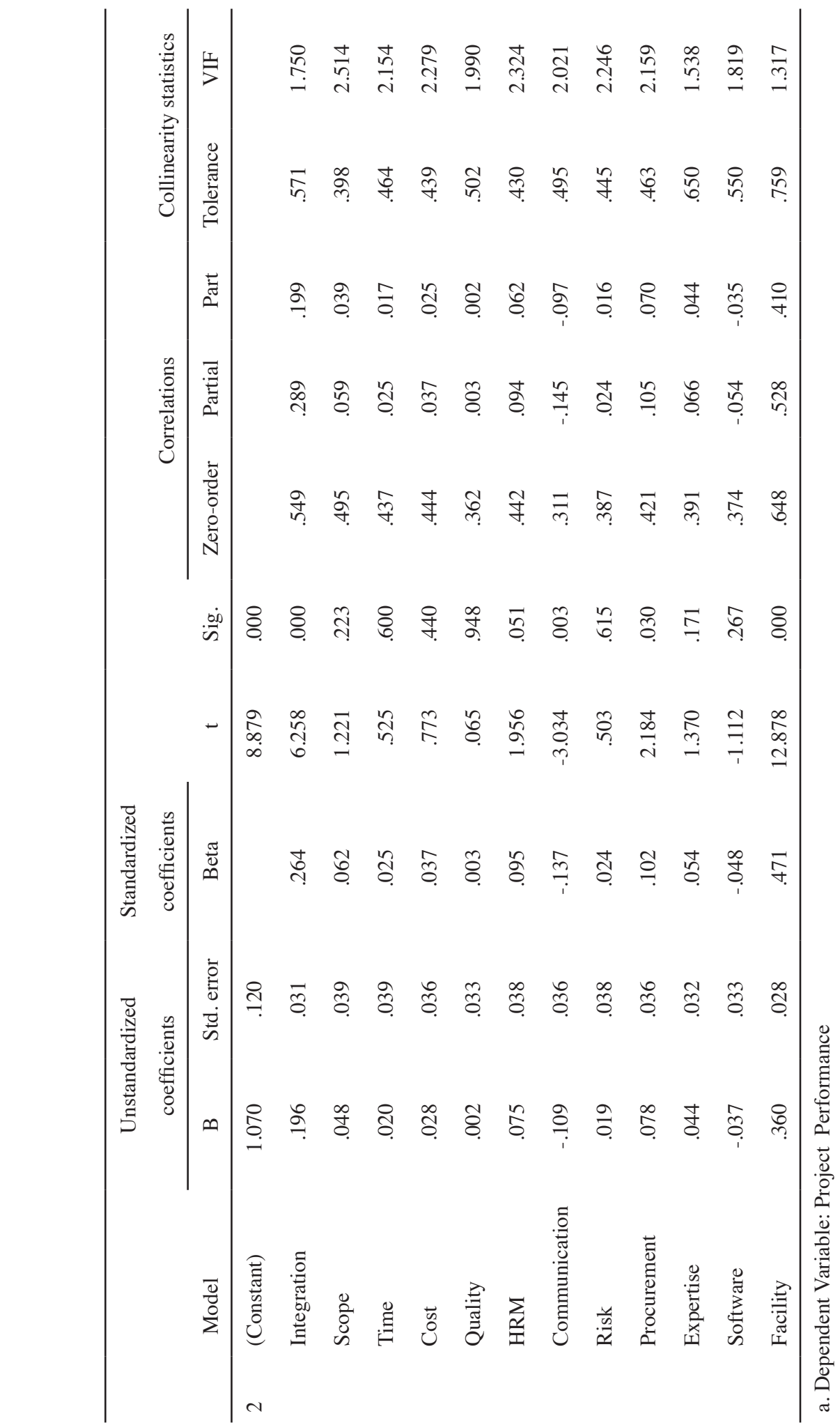


Malaysian Management Journal Vol. 17, 77-113 (2013)

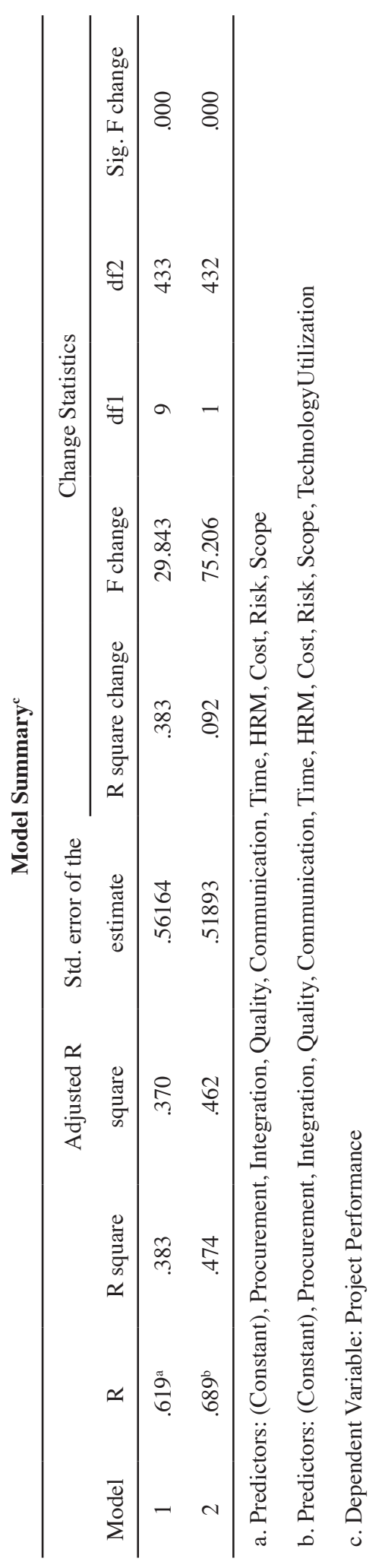




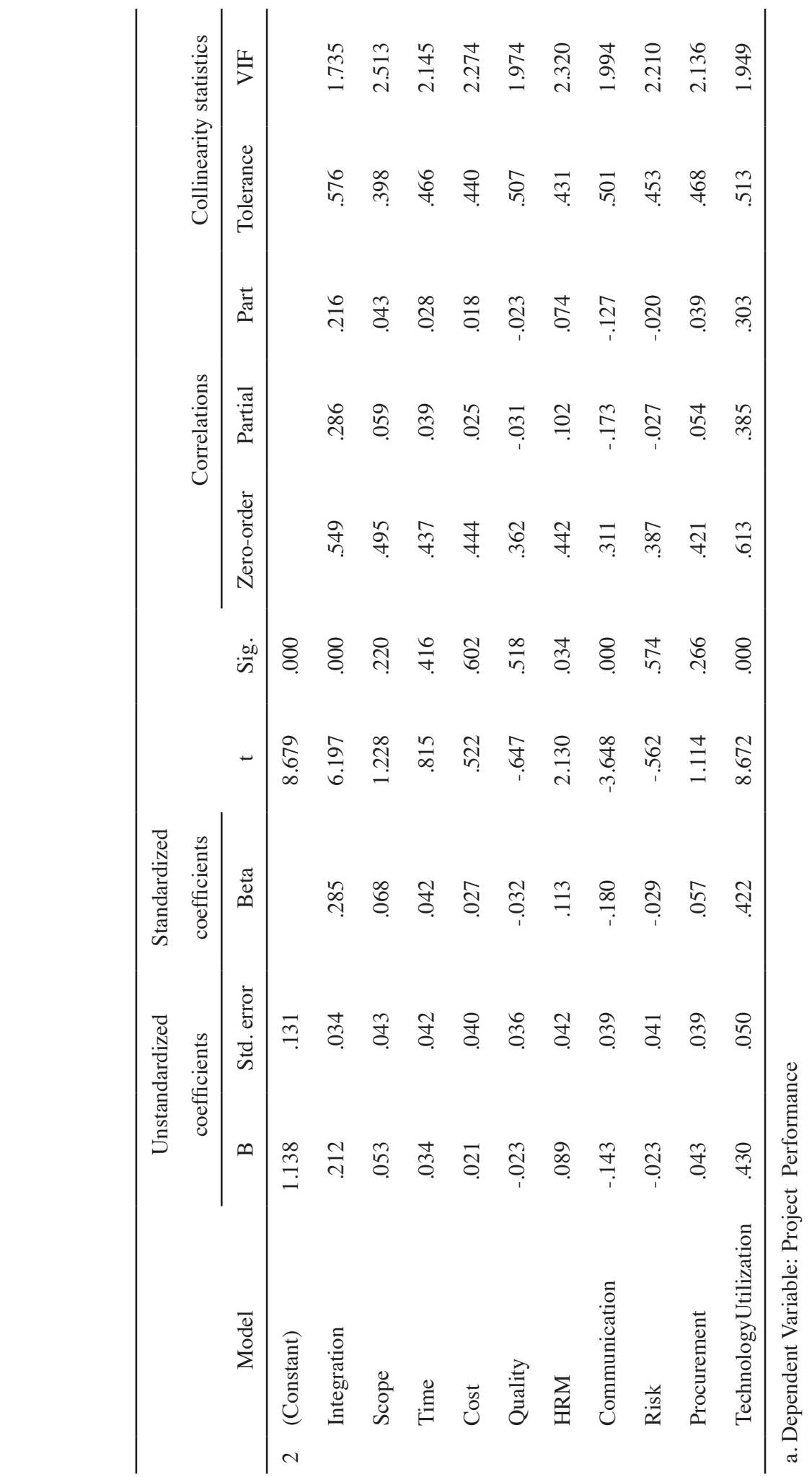


